\title{
Habilidades de Personal Software Process (PSP) para la industria del software en Latinoamérica
}

BRIAN PANDO SOTO ${ }^{1}$ GLEN RODRÍGUEZ RAFAEL ${ }^{2}$

\begin{abstract}
RESUMEN
La investigación abarca las habilidades técnicas y blandas requeridas en el desarrollo de software, puesto que es una actividad demandada por el mundo. Estas habilidades son necesarias para desempeñarse con destreza en una carrera tan globalizada y competitiva. Estudios previos muestran la existencia de una brecha entre la industria y la academia; los centros de formación proveen a los profesionales de habilidades técnicas, pero en estos últimos tiempos, se manifiesta la necesidad de contar con habilidades blandas, por lo que es clave estudiarlas y encontrar maneras de poder insertarlas en los profesionales que se integran a la industria. La aplicación de la metodología Personal Software Process (PSP) ayuda al estudiante a fortalecer sus destrezas en el proceso de desarrollo de software; no obstante, no es muy difundida en la academia ni en la industria. Este artículo muestra la importancia de las habilidades blandas, según las empresas latinoamericanas y el aporte del PSP para reducir la brecha de estas habilidades.
\end{abstract}

Palabras clave: Personal Software Process (PSP); habilidades blandas; brecha; industria del software.

\section{INTRODUCCIÓN}

De acuerdo con Bosch (2016), la producción de software es una actividad de continuo crecimiento, es por ello que Thurner, Schlierkamp, Böttcher y Zehetmeier (2016) señalan que cada vez se solicita ingenieros con mayores competencias. En los anuncios de trabajo relacionados a la ingeniería de software se observa que las habilidades demandadas se combinan entre habilidades técnicas y blandas (Ehlers, 2015; Oguz y Oguz, 2019); no obstante, existe una brecha de estas habilidades entre los graduados y los que la industria demanda (Akdur, 2019; Garousi, Giray, Tüzün, Catal y Felderer, 2019). Con respecto a los proyectos de software, el $52.7 \%$ se completan pasado el tiempo y presupuesto estimado; una de las causas es la falta de individuos competentes en el equipo de trabajo (Fitria y Nugraha, 2018). Asimismo, según Cárdenas-Castro, Gil y Rodríguez (2019), el desarrollo de software es una actividad tanto técnica como social, por ello, se necesita también contar con habilidades blandas, pero los ingenieros ingresan al mercado laboral sin entrenarse en estas habilidades. Esto se convierte en una de las causas principales de esta brecha, la cual requiere, en promedio, tres años para que los profesionales ganen la experiencia y destreza necesaria (Oguz y Oguz, 2019). Para el 2030 se pronostica un incremento de $30 \%$ en la demanda de habilidades blandas (Margarov y Konovalova, 2019).

Para Matturro, Raschetti y Fontán (2015), desde hace algunos años se han empezado a valorar las habilidades blandas en los profesionales por su influencia positiva en el trabajo; es por ello que esta industria manifiesta la necesidad de que los egresados cuenten con habilidades blandas (Rosca, 2018), al igual que los métodos ágiles expresan el requerimiento de estas habilidades (Diel, Bergmann, Marczak y Luciano, 2015).

$1 \quad$ Ingeniero en Informática y Sistemas por la Universidad Nacional Agraria de la Selva (Tingo María, Perú). Actualmente, es docente de dicha casa de estudios. (Tingo María, Perú). ORCID: https://orcid.org/0000-0002-8133-631X E-mail: brian.pando@unas.edu.pe

2 Doctor en Ingeniería Electrónica y de la Información por la Universidad Tecnológica de Toyohashi (Toyohashi, Japón). Actualmente, es docente de la Universidad Nacional Mayor de San Marcos. (Lima, Perú).

ORCID: https://orcid.org/0000-0002-4471-3198

E-mail: grodriguezr@unmsm.edu.pe 
A modo de resolver esta brecha entre la industria y la academia, los trabajos revisados sugieren propuestas, como establecer un programa de entrenamiento para los estudiantes (Mann, Kumar y Saini, 2015); actualizar el currículo para incluir la experiencia de la industria en la academia y entrenar a las personas antes de contratarlas - creación de programas de certificación- (Tüzün, Erdogmus y Ozbilgin, 2018); integrar proyectos reales (Pinto, Ferreira, Souza, Steinmacher y Meirelles, 2019); y que las agencias acreditadoras coloquen en mejor posición a las instituciones de formación en ingeniería que se enfocan en reducir la brecha (Alboaouh, 2019). Por otra parte, Yonamine et al. (2015) sugieren contar con herramientas que permitan medir y visualizar las habilidades del desarrollador. Sin embargo, también existen alternativas más concretas; por ejemplo, Mansoor, Bhutto, Bhatti, Patoli y Ahmed (2017) proponen proveer habilidades al desarrollador con PSP, combinado con otras prácticas; Gómez, Gasca, Manrique y Arias (2016) indican que las estrategias de enseñanza deben permitir a los estudiantes mejorar la calidad de sus productos de software; y, finalmente, Gasca, Gómez, Manrique y Arias (2015) señalan que un marco de trabajo para el diagnóstico de enseñanza de diseño de software, utilizando el PSP, resulta beneficioso.

El PSP, propuesto por Humphrey (2000), es una metodología que permite a un individuo mejorar, de forma continua, sus destrezas al desempeñarse en el proceso de creación de software, a través de mediciones y buenas prácticas. El objetivo del
PSP es desarrollar un software a tiempo y dentro de las estimaciones calculadas (López-Martín, Nassif y Abran, 2017). Este método provee habilidades técnicas para asegurar la calidad en el proceso de software, así como fortalecer algunas habilidades blandas. Los beneficios del PSP sobre las habilidades técnicas están demostradas en diversas investigaciones, tanto en la academia (Rong, Zhang, Qi y Saho, 2016) como en la industria (Urbina, Abud, Peláez, Alor y Sánchez, 2016); no obstante, se desconoce la importancia de las habilidades blandas promovidas por el PSP.

En el artículo se busca incentivar al fomento de la integración del método en la academia y en la industria. En la metodología se describe la manera como se realizó esta investigación; después, se presentan los resultados estadísticos, y, finalmente, se discute el contenido del trabajo y se señalan las conclusiones.

\section{METODOLOGÍA}

\section{Exploración de anuncios de trabajo}

Se revisaron las habilidades blandas solicitadas en 100 anuncios de trabajo de las plataformas web Aptitus y Computrabajo, en todas sus versiones para Latinoamérica (ver Figura 1). De la lista de habilidades solicitadas, se encontró que muchas de ellas tenían nombres distintos, pero se referían a la misma. Se categorizaron las habilidades por fases del desarrollo de software, basadas en los criterios de

\begin{tabular}{|c|c|c|}
\hline Requisitos (RQ) & & Diseño (DI) \\
\hline \multirow{3}{*}{$\begin{array}{l}\text { 1. Tratar con el usuario } \\
\text { 2. Tratar con el equipo } \\
\text { 3. De comunicación frecuente } \\
\text { 4. Extrovertido }\end{array}$} & & \multirow{3}{*}{$\begin{array}{l}\text { 5. Análisis y resolución de } \\
\text { problemas } \\
\text { 6. Separar problemas en } \\
\text { componentes } \\
\text { 7. Innovador }\end{array}$} \\
\hline & Integrales (IN) & \\
\hline & \multirow{4}{*}{$\begin{array}{l}\text { 14. Hab. gestión de configuración } \\
\text { 15. Enfocado en la calidad } \\
\text { 16. Hab. gestión de SE } \\
\text { 17. Conocer herr. y métodos SE } \\
\text { 18. Conocer proceso SE } \\
\text { 19. Medir y organizar sus tiempos } \\
\text { 20. Pronosticar duración de tareas }\end{array}$} & \\
\hline & & \\
\hline Construcción (CO) & & Pruebas (PR) \\
\hline $\begin{array}{l}\text { 8. De mente abierta } \\
\text { 9. Introvertido } \\
\text { 10. Pensante } \\
\text { 11. Receptivo }\end{array}$ & & $\begin{array}{l}\text { 12. Receptivo y buen juicio } \\
\text { 13. Conocer pruebas unitarias } \\
\text { hasta de integración }\end{array}$ \\
\hline
\end{tabular}

Figura 1. Habilidades blandas encontradas en la exploración de anuncios de trabajo de las plataformas web revisadas en la investigación.

Fuente: Elaboración propia. 
Matturro (2013). Estas habilidades fueron organizadas según estas fases y una categoría transversal denominada integrales.

Los anuncios fueron buscados con la palabra "software" y se consideraron los anuncios que hacían referencia al desarrollo de este; por lo que se descartaron otros puestos laborales, como atención al cliente, postventa de software, venta de software propietario y aquellos desligados al proceso del desarrollo. La lista de habilidades organizadas fue revisada por tres profesionales líderes de equipos de desarrollo de software.

\section{Diseño de encuesta para las empresas}

Se elaboró un cuestionario virtual con preguntas cortas para los reclutadores de empresas de desarrollo de software. El objetivo fue verificar si las empresas latinoamericanas demandan las habilidades blandas que PSP promueve. Para responder la encuesta, el reclutador debía ser ingeniero de software o afín, con por lo menos un año de experiencia como jefe de proyectos de software.

Las preguntas del cuestionario fueron validadas mediante el método Delphi por tres expertos con una prueba binomial. La confiabilidad del cuestionario, según el alfa de Cronbach en el software $\mathrm{R}$, fue de 0.94 , lo que implica un alto grado de confiabilidad en las respuestas.

Para determinar el número de empresas a encuestar, se tomó en cuenta el reporte de empresas de certificados en CMMi-Dev, según el Ministerio de Tecnologías de la Información y las Comunicaciones (2015), por los países de la Tabla 1. Por cálculo de muestra estadística con $\mathrm{N}=144, \mathrm{Z}=1.645$, e = $6.6 \%$ y $p=50 \%$, se llegó a un total de 49 empresas.

Tabla 1. Resumen de empresas certificadas CMMi-Dev, según niveles de madurez.

\begin{tabular}{|l|c|c|c|c|}
\hline País & Nivel 3 & Nivel 4 & Nivel 5 & Total \\
\hline Bolivia & 1 & 0 & 0 & 1 \\
\hline Panamá & 1 & 0 & 0 & 1 \\
\hline Ecuador & 1 & 0 & 1 & 2 \\
\hline Perú & 15 & 0 & 3 & 18 \\
\hline Chile & 10 & 0 & 4 & 14 \\
\hline Brasil & 45 & 1 & 6 & 52 \\
\hline Colombia & 44 & 0 & 12 & 56 \\
\hline Total & 117 & 1 & 26 & 144 \\
\hline
\end{tabular}

Fuente: Datos obtenidos a partir del MinTIC (2015).

El medio de contacto con estas empresas fue vía referencias profesionales e internet, invitándolos a responder el cuestionario publicado en Google For$\mathrm{ms}$. Las preguntas fueron diseñadas para responder, mediante la escala de Likert del 1 al 5 , sobre la importancia de cada habilidad en sus trabajadores dedicados al proceso de software.

El catálogo de empresas a encuestar fue elaborado a partir de las asociaciones de empresas relacionadas a TI en Argentina (Cámara de Empresas de Software y Servicios Informáticos), Bolivia (Cámara Boliviana de Tecnologías de la Información), Chile (Asociación Chilena de Empresas de Tecnologías de Información y Chiletec), Colombia (Federación Colombiana de la Industria de Software y TI), Ecuador (Asociación Ecuatoriana de Software), México (Asociación Mexicana del Transporte Intermodal y Cámara Nacional de la Industria Electrónica, de Telecomunicaciones y Tecnologías de la Información), Paraguay (Cámara Paraguaya de la Industria del Software), Perú (Asociación Peruana de Desarrolladores de Software y Servicios Relacionados), Uruguay (Cámara Uruguaya de Tecnologías de la Información) y Venezuela (Cámara Venezolana de Empresas de Tecnologías de la Información).

\section{Diseño de encuesta para profesionales de PSP}

Se elaboró un cuestionario virtual con preguntas cortas para los profesionales de PSP para determinar si, luego de haber sido formado con el curso de certificación, pudieron fortalecer la lista de habilidades blandas en estudio. Se utilizaron las mismas preguntas realizadas en la encuesta de las empresas, solo cambió el enfoque de la respuesta; es decir, a la empresa se le preguntó por la importancia de la habilidad, mientras que al profesional por el grado de mejora de cada habilidad luego de su formación. El protocolo de esta encuesta fue el mismo que el de la trabajada con las empresas.

El perfil del encuestado solicitaba que el colaborador haya llevado el curso oficial de PSP y obtenido su certificado, también debía contar con por lo menos un año de experiencia en la industria del software. Considerando al universo de las personas certificadas y que laboran en Latinoamérica, por una relación lógica con la confirmación de la existencia de 480 certificados en PSP en Colombia (Ministerio de Tecnologías de la Información y las Comunicaciones, 2015), se elaboró la tabla de referencia para el cálculo de muestra (ver Tabla 2).

El cálculo de muestra estadística obedeció a $\mathrm{N}=$ $1235, Z=1.645$, e $=20 \%$ y $p=50 \%$, y el total fue de 15 profesionales, a los que también se contactó vía referencias personales y redes sociales; estos 
fueron invitados a responder una encuesta virtual en Google Forms. Este cuestionario también fue validado por los tres expertos mencionados anteriormente. El alfa de Cronbach calculado fue de 0.94 , asegurando la confianza de las respuestas. El catálogo de profesionales a encuestar fue elaborado a partir de redes de trabajo UpWork y Workana, además de Foros y Blogs y otras redes sociales usadas en Latinoamérica.

Tabla 2. Cálculo de profesionales certificados en PSP por país en Latinoamérica.

\begin{tabular}{|l|c|c|}
\hline País & CMMi-Dev & PSP \\
\hline Bolivia & 1 & 9 \\
\hline Panamá & 1 & 9 \\
\hline Ecuador & 2 & 17 \\
\hline Perú & 18 & 154 \\
\hline Chile & 14 & 120 \\
\hline Brasil & 52 & 446 \\
\hline Colombia & 56 & 480 \\
\hline Total & 144 & 1235 \\
\hline
\end{tabular}

Fuente: Elaboración propia.

\section{Consideraciones para el procesamiento de respuesta en ambas encuestas}

De los cuestionarios no completados, solo se consideraron las respuestas válidas. La escala de Likert fue expresada de la siguiente manera: nada, poco, importante, mucho, alto. Se descartaron las habilidades nada importantes, de acuerdo con las respuestas de las empresas. Para calcular la brecha, se compararon las medias de las respuestas de las empresas y de los profesionales por cada habilidad.

\section{RESULTADOS}

Las empresas consideraron importante que sus empleados involucrados en las fases del desarrollo de software cuenten con la mayoría de las habilidades cuestionadas. En general, existe una mediana de valoración 4; es decir, muy importante (ver Figura 2). Dos habilidades se descartaron, las de ser introvertido y de ser extrovertido, por no ser de mucha importancia. Sin embargo, se debe tener en cuenta que para algunas empresas sí tiene valor si una persona es extrovertida para el reclutamiento en la fase de requisitos.

Por otro lado, el análisis de distribución de las respuestas de las empresas (ver Figura 3) muestra una tendencia hacia la derecha de la escala de Likert, a partir de importante, muy importante y altamente importante, con un $91 \%$ de las respuestas hacia esos valores.

Del mismo modo, al consultar a los profesionales PSP si habían conseguido fortalecer sus habilidades blandas, luego del curso de formación, estos
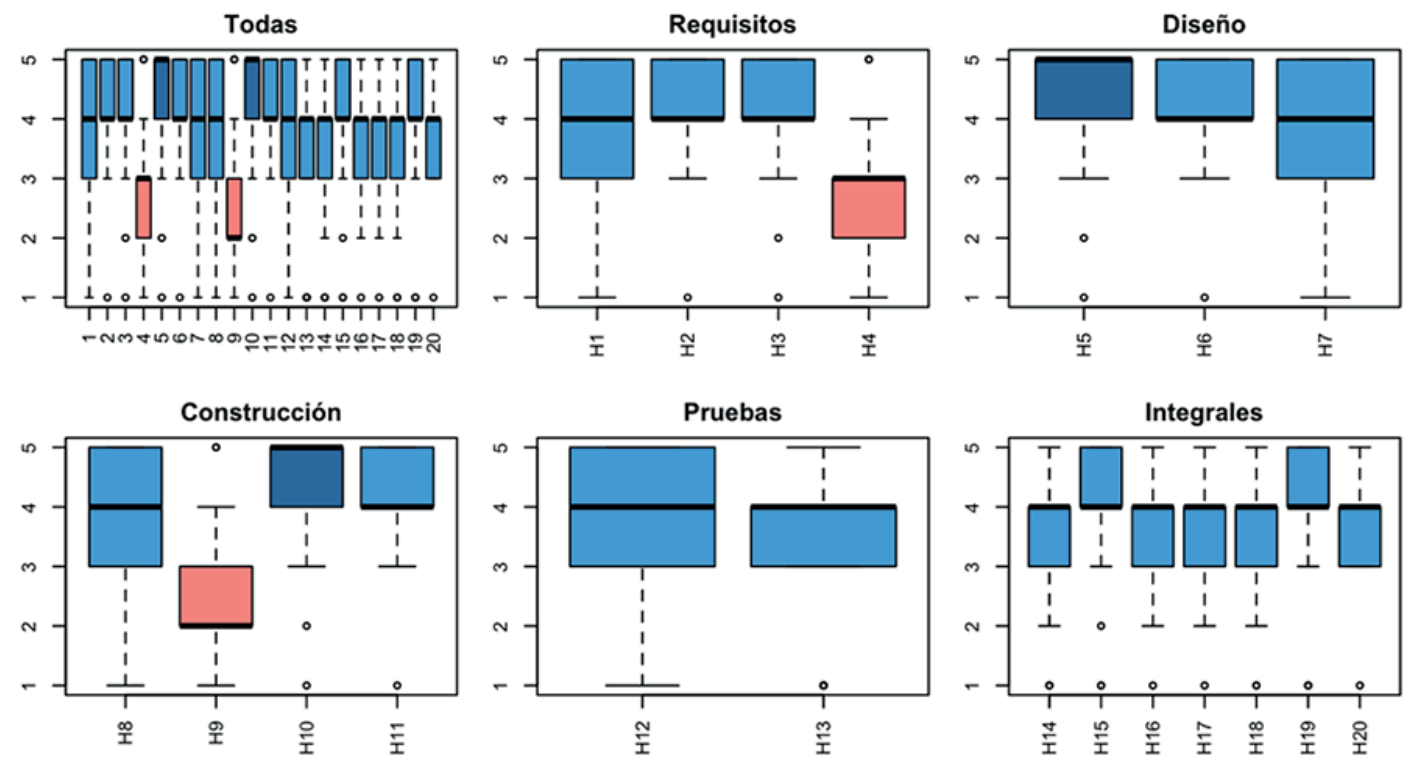

Figura 2. Gráficos de caja y bigote de la importancia de las habilidades blandas según las empresas de software en Latinoamérica.

Fuente: Elaboración propia. 
manifestaron resultados positivos en todas las habilidades, exceptuando las de introvertido y extrovertido, lo que demostró que la mayoría de las habilidades han sido fortalecidas con una mediana de 5 .

Al comparar los resultados de cada habilidad, se manifestó que la media de los profesionales superaba levemente lo requerido por la industria (ver Figura 5). El análisis de los resultados por cada fase de software indicó que la mediana de habilidades de los profesionales tiende a ser 5 , mientras que la de la empresa se mantiene en 4 , lo que señala que para la empresa las habilidades en cada fase son muy importantes y que los profesionales de PSP las tienen.

Habiendo confirmado la no normalidad de los datos, se aplicó el estadístico de prueba no paramétrica $U$ de Mann-Withney-Wilcoxon (ver Figura 6), lo que resultó $\mathrm{p}$-value $=0.9985$; este dato confirma
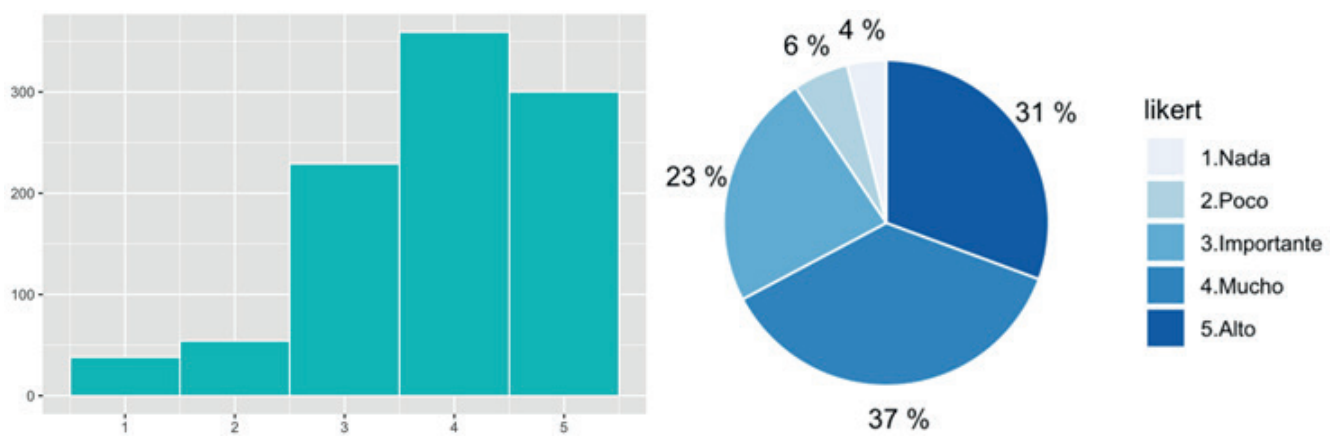

Figura 3. Gráficos de distribución y pastel de las respuestas de las empresas de software en Latinoamérica. Fuente: Elaboración propia.

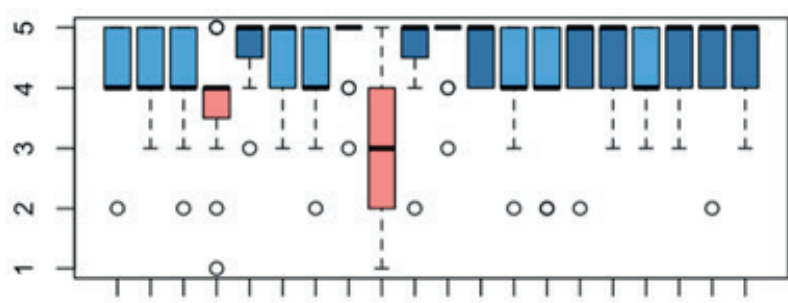

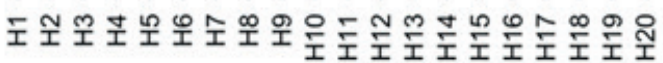

Min. 1st Qu. Median Mean 3rd Qu. Max. $\begin{array}{lllll}1.00 \quad 4.00 & 5.00 & 4.35 & 5.00 & 5.00\end{array}$

Figura 4. Gráficos de caja y bigote del fortalecimiento de las habilidades blandas según los profesionales PSP. Fuente: Elaboración propia.

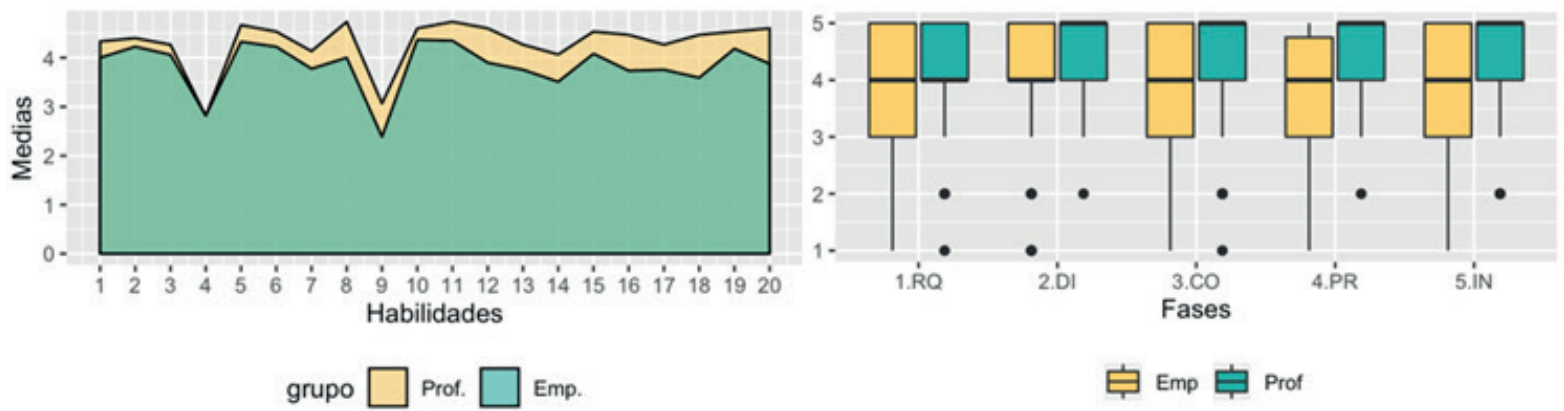

Figura 5. Gráficos de comparación de medias con área y bigote, entre las habilidades blandas requeridas por las empresas y lo conseguido por los profesionales PSP.

Fuente: Elaboración propia. 


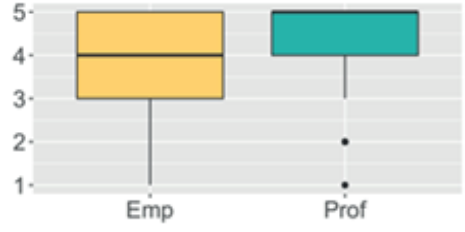

\begin{tabular}{lcccccc}
\hline \multicolumn{1}{c}{ Grupo } & Min & $1 \mathrm{Q}$ & Mediana & Media & $3 \mathrm{Q}$ & Max \\
\hline Prof. & 1 & 4 & 5 & 4.35 & 5 & 5 \\
Emp. & 1 & 3 & 4 & 3.86 & 5 & 5 \\
\hline U de Mann-Withney-Wilcoxon: W:103952, p-value $=0.9985$ \\
\hline
\end{tabular}

Figura 6. Análisis estadístico de comparación de medias con U de Mann-Withney-Wilcoxon.

Fuente: Elaboración propia.

que la media de valoración de los profesionales es superior a la de lo requerido por la industria.

Los resultados indican que las habilidades evaluadas son muy importantes para la empresa y que el PSP hace un importante aporte a estas habilidades, incluyendo las habilidades transversales a las fases. Esto indica que el PSP es un componente que se debe considerar para reducir la brecha entre la academia y la industria. En el análisis detallado de habilidades por fase se muestra que hay dos habilidades que se deben descartar, la de ser introvertido para la construcción de software y la de ser extrovertido para la fase de requisitos, pero se debe tomar en cuenta que para algunas empresas también es importante esta última habilidad.

\section{DISCUSIÓN}

Los resultados de Oguz y Oguz (2019) sugieren que una de las causas de la brecha entre la industria y la academia son las habilidades blandas, las cuales son desarrollas por el profesional en un aproximado de dos a tres años; además la industria manifiesta su interés por estas habilidades (Rosca, 2018). Los resultados de esta investigación indican que el PSP ayudaría a reducir esta brecha, al insertar al profesional en el sector laboral con las competencias que se requieren.

Por otra parte, Matturro, Raschetti y Fontán (2015) presentan las habilidades blandas para el equipo y el individuo, hallados ambos en los anuncios de trabajo. Sin embargo, este artículo se centró en las habilidades blandas, por tanto, encuentra una lista más extensa de las habilidades que engloban a las mencionadas por los autores. Asimismo, el programa de entrenamiento propuesto por Mann, Kumar y Saini (2015) podría incluir temas del PSP para no solo fortalecer habilidades técnicas, sino también blandas. Entre los programas de certificación mencionados, el planteado por Tüzün, Erdogmus y Ozbilgin (2018) debería considerar al PSP; del mismo modo, la integración con proyectos reales de Pinto,
Ferreira, Souza, Steinmacher y Meirelles (2019) debería incluir el PSP en los estudiantes, puesto que se conseguiría mayores logros en menos tiempo, lo que asegura la satisfacción también de la empresa.

Finalmente, la propuesta de Alboaouh (2019) podría no verse como un esfuerzo que represente un gran reto si se considera la combinación de las propuestas de Gasca et al. (2015), Mansoor et al. (2017) y Yonamine et al. (2015), en las que se atienden marcos de trabajo, herramientas y buenas prácticas, aplicando tanto las habilidades técnicas como las blandas, por lo que se podría apoyar de los resultados de esta investigación. Por último, se concuerda con lo manifestado en Gasca et al (2015) y Mansoor et al. (2017) sobre que el PSP tiene un aporte importante sobre las habilidades con las que el desarrollador debe contar; este trabajo suma a ambas investigaciones, desde la perspectiva de las habilidades blandas.

\section{CONCLUSIONES Y RECOMENDACIONES}

Se recomienda crear propuestas que integren las habilidades blandas en el proceso de formación de los estudiantes. También deben tomarse en cuenta la construcción de instrumentos y herramientas que faciliten el proceso de enseñanza de este método. Además, se debe incrementar los casos de estudio en los que se evidencien los beneficios y lecciones aprendidas al integrar el PSP en la academia y en las empresas. De las 20 habilidades blandas del estudio, 18 resultan muy importantes para la industria en la fase de requisitos, diseño, construcción, pruebas y las integrales, exceptuando introvertido para la construcción y extrovertido para los requisitos. Sin embargo, el análisis detallado de las habilidades permite destacar que para algunas empresas sí es importante ser extrovertido para la fase de requisitos.

Los profesionales deberían considerar adquirir estas habilidades blandas. No obstante, a pesar de que, por teoría, se centra en ayudar a un desarrollador de software para entender por qué se cometen 
errores y cómo encontrarlos, repararlos y prevenir a que vuelva a cometerlos, los resultados recolectados de los profesionales indican que el método PSP fomenta las habilidades blandas que la industria en Latinoamérica requiere, lo que satisface o supera levemente la necesidad. Por tanto, el método debería ser integrado desde el proceso de formación de los estudiantes para reducir la brecha de habilidades blandas solicitadas por la industria en los egresados.

Los resultados dejan abierta la discusión sobre la habilidad de comunicación frecuente y de tratar con miembros del equipo, ya que el PSP está enfocado en el trabajo individual, pero los profesionales indican que sí hubo impacto en estas habilidades.

\section{REFERENCIAS BIBLIOGRÁFICAS}

[1] Akdur, D. (2019). The Design of a Survey on Bridging the Gap between Software Industry Expectations and Academia. En $20198^{\text {th }}$ Mediterranean Conference on Embedded Computing (MECO 2019). Institute of Electrical and Electronics Engineers, Montenegro.

[2] Alboaouh, K. (2019). The Gap between Engineering Schools and Industry: A Strategic Initiative. En 2018 IEEE Frontiers in Education Conference (FIE). Institute of Electrical and Electronics Engineers, Estados Unidos.

[3] Bosch, J. (2016). Speed, Data, and Ecosystems: The Future of Software Engineering. Institute of Electrical and Electronics Engineers Software, 33(1), 82-88.

[4] Cárdenas-Castro, C., Gil, J. C. y Rodríguez, P. (2019). Soft Skills Training: Performance Psychology Applied to Software Development. En 2019 IEEE/ACM 12 ${ }^{\text {th }}$ International Workshop on Cooperative and Human Aspects of Software Engineering (CHASE). Institute of Electrical and Electronics Engineers, Canadá.

[5] Diel, E., Bergmann, M., Marczak, S. y Luciano, E. (2015). What is Agile, Which Practices are Used, and Which Skills are Necessary According to Brazilian Professionals: Findings of an Initial Survey. En $20156^{\text {th }}$ Brazilian Workshop on Agile Methods (WBMA). Institute of Electrical and Electronics Engineers, Brasil.

[6] Ehlers, J. (2015). Socialness in the Recruiting of Software Engineers. En Proceedings of the $12^{\text {th }}$ ACM International Conference on Computing Frontiers. Association for Computing Machinery, Italia.
[7] Fitria y Nugraha, I. G. B. B. (2018). Formation of Software Programmer Team Based on Skill Interdependency. En 2018 International Conference on Information Technology Systems and Innovation (ICITSI). Institute of Electrical and Electronics Engineers, Indonesia.

[8] Garousi, V., Giray, G., Tüzün, E., Catal, C. y Felderer, M. (2019). Closing the Gap between Software Engineering Education and Industrial Needs. Institute of Electrical and Electronics Engineers Software, 37(2), 68-77.

[9] Gasca, G. P., Gómez, M. C., Manrique, B. y Arias, D. M. (2015). Diagnostic on TeachingLearning of Software Desing by Using the Personal Software Process Framework. En $201510^{\text {th }}$ Iberian Conference on Information Systems and Technologies (CISTI). Institute of Electrical and Electronics Engineers, Portugal.

[10] Gómez, M. C., Gasca, G. P., Manrique, B. y Arias, D. M. (2016). Method of Pedagogic Instruments Design for Software Engineering. En $201611^{\text {th }}$ Iberian Conference on Information Systems and Technologies (CISTI). Institute of Electrical and Electronics Engineers Computer Society, España.

[11] Humphrey, W. S. (2000). The Personal Software Process (PSP). Software Engineering Institute. Recuperado de https://resources.sei.cmu.edu/ library/asset-view.cfm?assetid=5283.

[12] López-Martín, C., Nassif, A. B. y Abran, A. (2017). A Training Process for Improving the Quality of Software Projects Developed by a Practitioner. Journal of Systems and Software, 131, 98-111.

[13] Mann, K. S., Kumar, M. N. y Saini, H. S. (2015). The Major Challenges for Engineering Institutions to Fulfill Industry Demands in India. En 2015 IEEE $3^{\text {rd }}$ International Conference on MOOCs, Innovation and Technology in Education (MITE). Institute of Electrical and Electronics Engineers, India.

[14] Mansoor, S., Bhutto, A., Bhatti, N., Patoli, N. y Ahmed, M. (2017). Improvement of Students Abilities for Quality of Software Through Personal Software Process. En 2017 International Conference on Innovations in Electrical Engineering and Computational Technologies (ICIEECT). Institute of Electrical and Electronics Engineers, Pakistán.

[15] Margarov, G. y Konovalova, V. (2019). Interdisciplinary Competencies Needed for Engineers in the Digital Economy. En 
2019 Computer Science and Information Technologies (CSIT). Institute of Electrical and Electronics Engineers, Armenia.

[16] Matturro, G. (2013). Soft Skills in Software Engineering: A Study of its Demand by Software Companies in Uruguay. En 2013 $6^{\text {th }}$ International Workshop on Cooperative and Human Aspects of Software Engineering (CHASE). Institute of Electrical and Electronics Engineers, Estados Unidos.

[17] Matturro, G., Raschetti, F. y Fontán, C. (2015). Soft Skills in Software Development Teams: A Survey of the Points of View of Team Leaders and Team Members. En $20158^{\text {th }}$ International Workshop on Cooperative and Human Aspects of Software Engineering (CHASE). Institute of Electrical and Electronics Engineers, Italia.

[18] Ministerio de Tecnologías de la Información y las Comunicaciones (2015). Colombia líder en la región en la producción de software de calidad. Ministerio de Tecnologías de la Información y las Comunicaciones. Recuperado de http:// www.mintic.gov.co/portal/604/w3-article-8571. html.

[19] Oguz, D. y Oguz, K. (2019). Perspectives on the Gap between the Software Industry and the Software Engineering Education. Institute of Electrical and Electronics Engineers Access, 7, 117527-117543.

[20] Pinto, G., Ferreira, C., Souza, C., Steinmacher, I. y Meirelles, P. (2019). Training Software Engineers Using Open-Source Software: The Students' Perspective. En 2019 IEEE/ACM $41^{\text {st }}$ International Conference on Software Engineering: Software Engineering Education and Training (ICSE-SEET). Institute of Electrical and Electronics Engineers, Canadá.

[21] Rong, G., Zhang, H., Qi, S. y Shao, D. (2016). Can Software Engineering Students Program Defect-Free? An Educational Approach. En 2016 IEEE/ACM 38 th International Conference on Software Engineering Companion (ICSE-C). Institute of Electrical and Electronics Engineers, Estados Unidos.
[22] Rosca, D. (2018). Acquiring Professional Software Engineering Skills Through StudioBased Learning. En $201817^{\text {th }}$ International Conference on Information Technology Based Higher Education and Training (ITHET). Institute of Electrical and Electronics Engineers, Portugal.

[23] Thurner, V., Schlierkamp, K., Böttcher, A. y Zehetmeier, D. (2016). Integrated Development of Technical and Base Competencies: Fostering Reflection Skills in Software Engineers to Be. En 2016 IEEE Global Engineering Education Conference (EDUCON). Institute of Electrical and Electronics Engineers Computer Society, Emiratos Árabes Unidos.

[24] Tüzün , E., Erdogmus, H. y Ozbilgin, I. G. (2018). Are Computer Science and Engineering Graduates Ready for the Software Industry? Experiences from an Industrial Student Training Program. En 2018 40 In International Conference on Software Engineering: Software Engineering Education and Training (ICSE$S E E T)$. Institute of Electrical and Electronics Engineers, Suecia.

[25] Urbina, M. L., Abud, M. A., Peláez, G., Alor, G. y Sánchez, A. I. (2016). Propuesta de un modelo de integración de PSP y Scrum para mejorar la calidad del proceso de desarrollo en una MiPyME. Research in Computing Science, 120, 147-157.

[26] [26] Yonamine, T., Yajima, K., Takeichi, Y., Sato, J., Kato, Y. y Yamazaki, M. (2015). A Means for Visualization of Skills in Software Development. En $20157^{\text {th }}$ International Conference on Information Technology and Electrical Engineering (ICITEE). Institute of Electrical and Electronics Engineers, Tailandia. 


\section{Personal Software Process (PSP) Skills for the Software Industry in Latin America}

BRIAN PANDO SOTO ${ }^{1}$ GLEN RODRÍGUEZ RAFAEL ${ }^{2}$

\begin{abstract}
This research covers the technical and soft skills required in software development, a globally in-demand activity. These skills are required to efficiently perform in a very globalized, competitive field. Previous studies show the existence of a gap between industry and academia. Training centers provide professionals with technical skills, but as of late, the need for soft skills has become apparent, making it important to study and find ways to embed them into the professionals who join the industry. The application of Personal Software Process (PSP) methodology helps students to strengthen their skills in the software development process, however, the method is not widespread in academia nor industry. This article shows the importance of soft skills, according to Latin American companies, and how PSP can reduce the skills gap.
\end{abstract}

Keywords: Personal Software Process (PSP); soft skills; gap; software industry.

\section{INTRODUCTION}

According to Bosch (2016), software production is a continuously growing activity, which is why Thurner, Schlierkamp, Bottcher, and Zehetmeier (2016) state that more-skilled engineers are always being requested. In software engineering job postings it is observed that in-demand skills combine both technical and soft skills (Ehlers, 2015; Oguz \& Oguz, 2019). Nevertheless, there is a skills gap between graduates and what the industry demands (Akdur, 2019; Garousi, Giray, Tüzün, Catal \& Felderer, 2019). With respect to software projects, $52.7 \%$ exceed estimated time and budget; one of the causes is the lack of competent individuals on the work team (Fitria \& Nugraha, 2018). Similarly, Cárdenas-Castro, Gil and Rodríguez (2019) argue that software development is both a technical and a social activity, so that soft skills are also needed. However, engineers enter the labor market without training in these skills. This translates into one of the main causes of this skills gap, which, on average, takes professionals three years to gain the experience and skills required to bridge this gap (Oguz \& Oguz, 2019). A 30\% increase in the demand for soft skills is predicted by 2030 (Margarov \& Konovalova, 2019).

According to Matturro, Raschetti and Fontán (2015), soft skills, for some years now, have begun to be appreciated in professionals for their positive influence on the workplace;. this is why the industry expresses the need for graduates with soft skills (Rosca, 2018), in the same way, agile methodologies require these skills (Diel, Bergmann, Marczak \& Luciano, 2015).

To address this gap between industry and academia, the papers reviewed suggest recommendations, such as the establishment of a training program for students (Mann, Kumar \& Saini, 2015); updating curriculum to insert industry experience

1 Computer and Systems engineer from the Universidad Nacional Agraria de la Selva (Tingo María, Peru), currently working as professor at said institution.

ORCID: https://orcid.org/0000-0002-8133-631X

E-mail: brian.pando@unas.edu.pe

$2 \mathrm{PhD}$ in Electronic and Information Engineering from Toyohashi University of Technology. Currently working as professor at Universidad Nacional Mayor de San Marcos. (Lima, Peru). ORCID: https://orcid.org/0000-0002-4471-3198 E-mail: grodriguezr@unmsm.edu.pe 
into academia and training before hiring; the creation of certification programs- (Tüzün, Erdogmus \& Ozbilgin, 2018); the inclusion of real-world projects (Pinto, Ferreira, Souza, Steinmacher \& Meirelles, 2019); and that accrediting agencies grant higher rankings to engineering schools that focus on reducing the gap (Alboaouh, 2019). On the other hand, Yonamine et al. (2015) suggest relying on tools that allow for the measurement and visualization of the developer's skills. However, more concrete alternatives exist. For example, Mansoor, Bhutto, Bhatti, Patoli and Ahmed (2017) propose providing skills to the developer through PSP combined with other practices; Gómez, Gasca, Manrique and Arias (2016) state that teaching strategies should allow students to improve the quality of their software products; finally, for Gasca, Gómez, Manrique and Arias (2015) a framework for a diagnostic of teaching software design using the Personal Software Process (PSP) is beneficial.

The PSP proposed by Humphrey (2000) is a methodology that allows individuals to continuously improve their skills when performing in the software development process through measurements and good practices. The objective of the PSP is to develop software on time and under budget (López-Martín, Nassif \& Abran, 2017). This method provides technical skills to ensure quality in the software process, as well as strengthen certain soft skills. The benefits of PSP over technical skills are demonstrated in various research both in academia (Rong, Zhang, Qi \& Saho, 2016) and in industry (Urbina, Abud, Peláez, Alor \& Sánchez, 2016); however, the importance of soft skills promoted by PSP is not known.

This article aims to encourage the integration of the PSP method in both academia and industry. The methodology section of this work describes the way this research was conducted; then, statistical results are presented, and finally, the content of the work is discussed and the conclusions are stated.

\section{METHODOLOGY}

\section{Scanning job postings}

The soft skills requested in 100 job postings on the Aptitus and Computrabajo web platforms, in all their versions for Latin America, were reviewed (see Figure 1). Many of the skills requested on these lists had different names, but referred to the same skill. Skills were categorized by software development phases, based on Matturro's criteria (2013). These skills were organized according to these software development phases and according a cross-cutting category called Comprehensive.

The postings were searched with the keyword "software" and those that referred to software development were considered; therefore, other jobs were discarded, such as customer service, software after-sales service, sale of proprietary software and those unrelated to the development process. The

\begin{tabular}{|c|c|c|}
\hline Requirements (RQ) & & Design (DE) \\
\hline \multirow[t]{2}{*}{$\begin{array}{l}\text { 1. Customer-oriented } \\
\text { 2. Team player } \\
\text { 3. Communication skills } \\
\text { 4. Extroverted personality }\end{array}$} & & \multirow[t]{2}{*}{$\begin{array}{l}\text { 5. Analysis and problem- } \\
\text { solving } \\
\text { 6. Problem-mapping } \\
\text { 7. Innovative }\end{array}$} \\
\hline & Comprehensive (CM) & \\
\hline & \multirow{4}{*}{$\begin{array}{l}\text { 14. Configuration management } \\
\text { skills } \\
\text { 15. Quality-focused } \\
\text { 16. SE management skills } \\
\text { 17. Knowledge of SE tools and } \\
\text { methods } \\
\text { 18. Knowledge of SE process } \\
\text { 19. Time management and } \\
\text { organization. } \\
\text { 20. Project forecasting }\end{array}$} & \\
\hline Construction (CO) & & Testing (TS) \\
\hline \multirow[t]{2}{*}{$\begin{array}{l}\text { 8. Open-minded } \\
\text { 9. Introverted personality } \\
\text { 10. Deep thinker } \\
\text { 11. Receptive }\end{array}$} & & $\begin{array}{l}\text { 12. Receptive and of good } \\
\text { judgment } \\
\text { 13. Knowledge from unit to } \\
\text { integration testing }\end{array}$ \\
\hline & & \\
\hline
\end{tabular}

Figure 1. Soft skills found in the exploration of job postings of web platforms reviewed for this research. 
list of organized skills was reviewed by three professional software development team leaders.

\section{Survey design for businesses}

A virtual questionnaire with brief questions was developed for software development company recruiters. The objective was to verify if Latin American companies require the soft skills promoted by PSP. To answer the survey, the recruiter had to be a software engineer or related, with at least one year of experience as a software project manager.

The questions were validated through the Delphi method by three experts with a binomial test. The reliability of the questionnaire, according to Cronbach's alpha using R software, was 0.94 , which implies a high degree of reliability in the answers.

To determine the number of companies to survey, the report of CMMi-Dev certified companies was considered according to the Ministry of Information and Communication Technologies (2015) per country in Table 1. Using for the statistical sample calculation $\mathrm{N}=144, \mathrm{Z}=1.645, \mathrm{e}=6.6 \%$ and $\mathrm{p}=50 \%$, a total of 49 companies was reached.

Table 1. Summary of CMMi-Dev certified companies, according to maturity levels.

\begin{tabular}{|l|c|c|c|c|}
\hline Country & Level $\mathbf{3}$ & Level $\mathbf{4}$ & Level $\mathbf{5}$ & Total \\
\hline Bolivia & 1 & 0 & 0 & 1 \\
\hline Panama & 1 & 0 & 0 & 1 \\
\hline Ecuador & 1 & 0 & 1 & 2 \\
\hline Peru & 15 & 0 & 3 & 18 \\
\hline Chile & 10 & 0 & 4 & 14 \\
\hline Brazil & 45 & 1 & 6 & 52 \\
\hline Colombia & 44 & 0 & 12 & 56 \\
\hline Total & 117 & 1 & 26 & 144 \\
\hline
\end{tabular}

Source: Data obtained from MinTIC (2015).

These companies were contacted via professional and internet references, inviting them to answer the questionnaire published on Google Forms. The questions addressed the importance of each skill on their software development workers.

The catalogue of companies to survey was developed from IT-related company associations in Argentina (Cámara de Empresas de Software y Servicios Informáticos), Bolivia (Cámara Boliviana de Tecnologías de la Información), Chile (Asociación Chilena de Empresas de Tecnologías de Información y Chiletec), Colombia (Federación Colombiana de la Industria de Software y TI), Ecuador (Asociación Ecuatoriana de Software), Mexico
(Asociación Mexicana del Transporte Intermodal y Cámara Nacional de la Industria Electrónica, de Telecomunicaciones y Tecnologías de la Información), Paraguay (Cámara Paraguaya de la Industria del Software), Peru (Asociación Peruana de Desarrolladores de Software y Servicios Relacionados), Uruguay (Cámara Uruguaya de Tecnologías de la Información) and Venezuela (Cámara Venezolana de Empresas de Tecnologías de la Información).

\section{Survey design for PSP professionals}

A virtual questionnaire with short questions was developed for PSP professionals to determine if, after being trained with the certification course, they were able to strengthen the soft skills under study. The same questions asked in the company survey were used, only the focus of the answer changed; that is, the company was asked about the importance of the skill, while the professional was asked about the degree of improvement of each skill after their training. The protocol for this survey was the same as the one used for the companies.

The survey respondent profile was designed for people who had taken the official PSP course and obtained their certificate, and had at least one year of experience in the software industry. Considering the pool of certified people working in Latin America, confirmed by reason of the existence of 480 PSP certified individuals in Colombia (Ministerio de Tecnologías de la Información y las Comunicaciones, 2015), the reference table for the sample calculator was developed (see Table 2).

Table 2. Calculation of certified professionals in PSP per country in Latin America.

\begin{tabular}{|l|c|c|}
\hline Country & CMMi-Dev & PSP \\
\hline Bolivia & 1 & 9 \\
\hline Panama & 1 & 9 \\
\hline Ecuador & 2 & 17 \\
\hline Peru & 18 & 154 \\
\hline Chile & 14 & 120 \\
\hline Brazil & 52 & 446 \\
\hline Colombia & 56 & 480 \\
\hline Total & 144 & 1235 \\
\hline
\end{tabular}

Source: Prepared by the author.

The statistical sample calculation consisted of $\mathrm{N}$ $=1235, Z=1,645, e=20 \%$ and $p=50 \%$, with $a$ total of 15 professionals, who were also contacted via personal references and social networks; these were invited to respond to a virtual survey on Google Forms. This questionnaire was also validated by the three experts mentioned above. Cronbach's 
alpha was 0.94 , which ensured the confidence of the answers. The catalogue of professionals to be surveyed was compiled from the UpWork and Workana networks, in addition to forums and blogs and other social networks used in Latin America.

\section{Considerations for response processing in both surveys}

Of the uncompleted questionnaires, only valid responses were considered. The Likert scale was expressed as follows: unimportant, of little importance, moderately important, important, very important. Unimportant skills were discarded, according to the companies' answers. To calculate the gap, the means of the companies' and professionals' responses per skill were compared.

\section{RESULTS}

The companies considered it important that their employees involved in the phases of software development possess most of the skills mentioned in the questionnaires. In general, there is a median of 4; that is to say, important (see Figure 2). Two skills were discarded, introverted and extroverted personality, as they were not considered to be of great importance. However, it should be noted that for some companies, during the recruitment phase, it is important if a person had an extroverted personality.
On the other hand, the distribution analysis of the companies' responses (see Figure 3 ) shows a trend towards the right of the Likert scale, from moderately important, important and very important, with $91 \%$ of the responses oriented towards these values.

Similarly, when asked if the PSP professionals had managed to strengthen their soft skills after the training course, they reported positive results in all skills except introverted and extroverted personality, showing that most skills have been strengthened with a median of 5 .

When comparing the results of each skill, it was shown that the mean of the professionals slightly exceeded industry requirements (see Figure 5). The analysis of the results for each software phase indicated that the median skills of the professionals tend to be 5 , while the company's remains at 4 , which indicates that, for the company, the skills in each phase are very important and that PSP professionals have them.

Having confirmed the nonnormality of the data, the nonparametric Mann-Withney-Wilcoxon $U$ statistical test was applied (see Figure 6), which resulted in a $p$-value $=0.9985$. This confirms that the mean of the professionals is higher than that required by the industry.
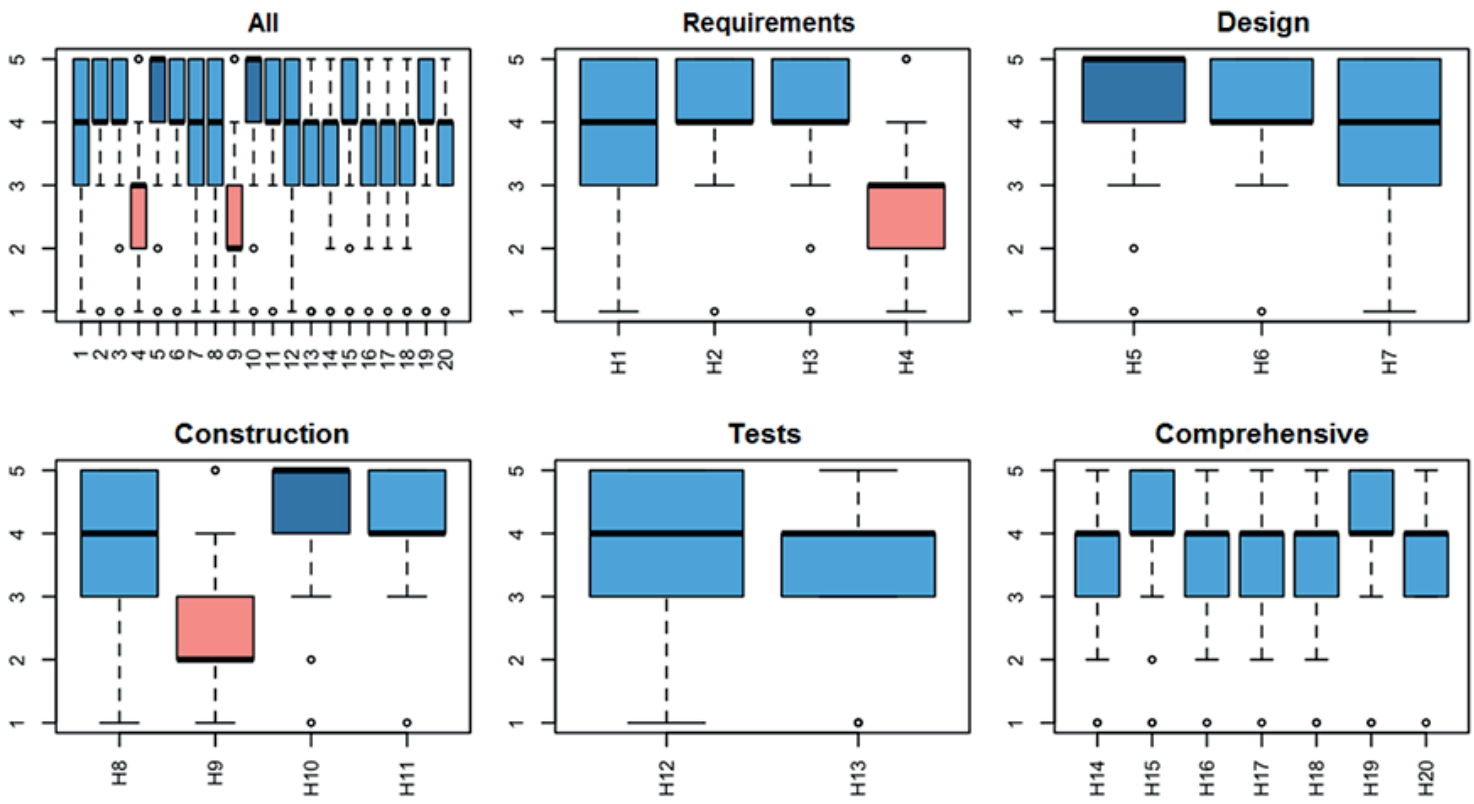

Figure 2. Box plot of the importance of soft skills according to software companies in Latin America. Source: Prepared by the author. 
The results indicate that the skills evaluated are important for the company and PSP contribution to these skills is important, including cross-cutting skills. This indicates that the PSP is a component that should be considered to reduce the gap between academia and industry. In the detailed analysis of skills per phase it is shown that there are two skills that should be discarded, introverted personality for the software construction and extroverted personality for the requirements phase; however, it should be kept in mind that for some companies the latter skill is considered important.

\section{DISCUSSION}

The results of Oguz and Oguz (2019) suggest that one of the causes of the gap between industry and academia is soft skills, which are developed by the professional in approximately two to three years; furthermore, the industry expresses its interest in
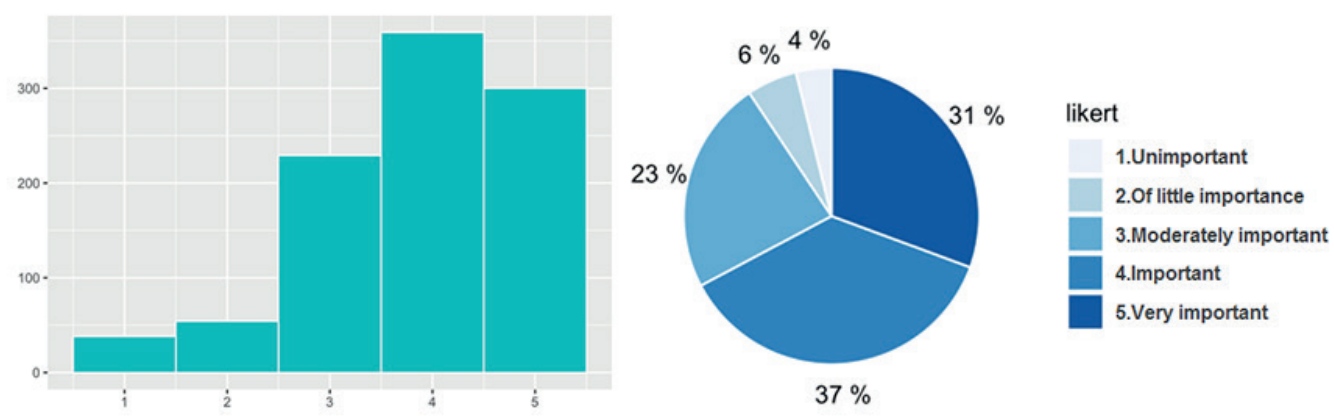

Figure 3. Distribution and pie graphs of the responses of software companies in Latin America. Source: Prepared by the author.

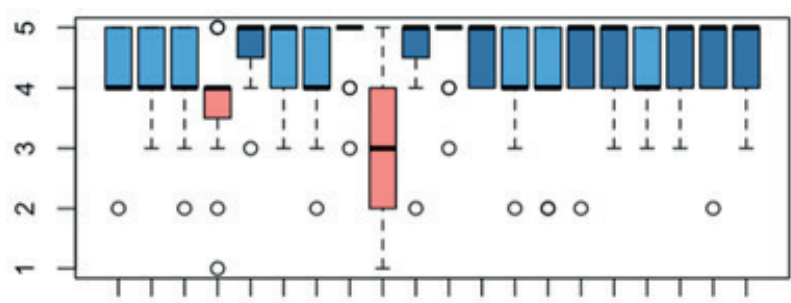

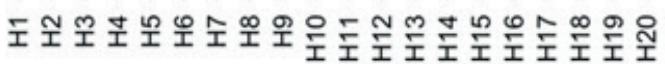

Min. 1st Qu. Median Mean 3rd Qu. Max.

Figure 4. Box plot of soft skills strengthening according to PSP professionals.

Source: Prepared by the author.
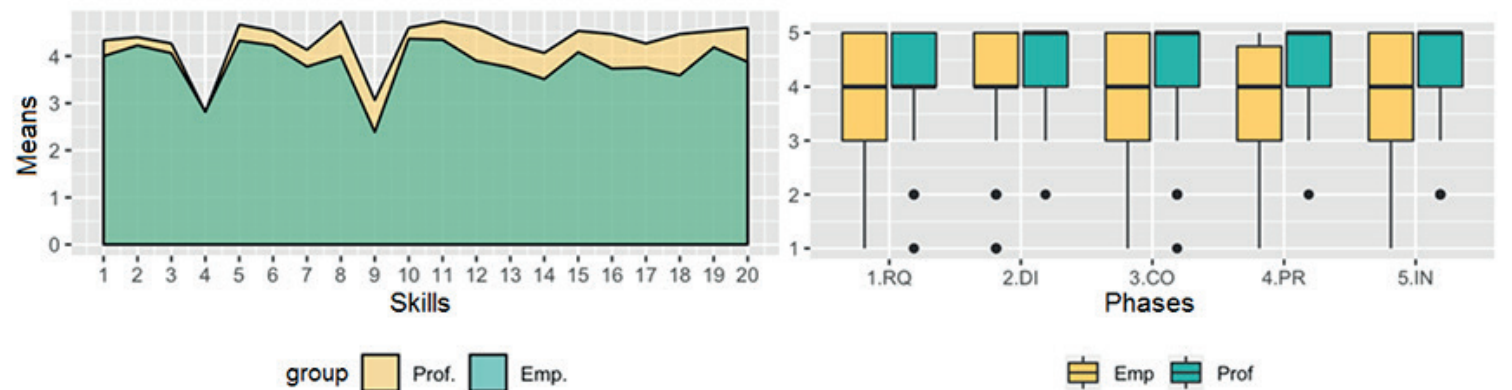

Figure 5. Area and box graphs comparing means of soft skills required by companies and what is achieved by PSP professionals.

Source: Prepared by the author. 


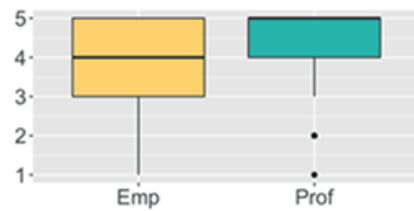

\begin{tabular}{lcccccc}
\hline Gruop & Min & $1 \mathrm{Q}$ & Median & Mean & $3 \mathrm{Q}$ & Max \\
\hline Prof. & 1 & 4 & 5 & 4.35 & 5 & 5 \\
Emp. & 1 & 3 & 4 & 3.86 & 5 & 5 \\
\hline U de Mann-Withney-Wilcoxon: W:103952, p-value $=0.9985$ \\
\hline
\end{tabular}

Figura 6. Statistical analysis to compare means using Mann-Withney-Wilcoxon U test.

Source: Prepared by the author.

these skills (Rosca, 2018). The results of this research indicate that PSP would help to reduce this gap by inserting the professional in the labor market with the required skills.

On the other hand, Matturro, Raschetti and Fontán (2015) present soft skills for the team and for the individual, both found in job postings. This article focused on soft skills; therefore, it finds a more extensive list of skills that encompasses those mentioned by the authors. Also, the training program proposed by Mann, Kumar and Saini (2015) could include PSP topics to strengthen not only technical but also soft skills. Among the certification programs mentioned, that proposed by Tüzün, Erdogmus and Ozbilgin (2018) should consider PSP; in the same way, the integration with real-world projects of Pinto, Ferreira, Souza, Steinmacher and Meirelles (2019) should include the PSP for students, since it would achieve more in less time, which also ensures company satisfaction.

Finally, Alboaouh's (2019) proposal may not be seen as a very challenging effort if one considers the combination of the proposals of Gasca et al. (2015), Mansoor et al. (2017) and Yonamine et al. (2015), which address frameworks, tools and good practices, applying both technical as well as soft skills, and could therefore be supported by the results of this research. Finally, the research agrees with Gasca et al (2015) and Mansoor et al. (2017) that PSP is an important contribution to the skills that the developer should have; this work combines both investigations, from the perspective of soft skills.

\section{CONCLUSIONS AND RECOMMENDATIONS}

It is recommended that proposals that integrate soft skills into the training process of students be created. The construction of instruments and tools that facilitate the teaching process of this method should also be considered. In addition, there should be more case studies in which the benefits and lessons learned from integrating PSP into academia and companies are demonstrated. Out of the 20 soft skills in this research, 18 proved very important for the industry in the requirements, design, construction, testing and comprehensive phases, with the exceptions of introverted personality for the construction and extroverted personality for the requirements phases. However, the detailed analysis of the skills made it possible to highlight that for some companies it is important to be extroverted for the requirements phase.

Professionals should consider acquiring these soft skills. However, despite the theoretical focus on helping a software developer understand why mistakes are made and how to find them, fix them and prevent them from being made again, results collected from professionals indicate that the PSP method promotes the soft skills that the industry in Latin America requires, meeting or slightly exceeding the need. Therefore, the method should be integrated starting from the student training process to reduce the gap of soft skills required in graduates by the industry.

The results leave open the discussion about communication and teamwork skills, as the PSP is focused on individual work, although professionals indicate that there was an impact on these skills.

\section{REFERENCES}

[1] Akdur, D. (2019). The Design of a Survey on Bridging the Gap between Software Industry Expectations and Academia. En $20198^{\text {th }}$ Mediterranean Conference on Embedded Computing (MECO 2019). Institute of Electrical and Electronics Engineers, Montenegro.

[2] Alboaouh, K. (2019). The Gap between Engineering Schools and Industry: A Strategic Initiative. En 2018 IEEE Frontiers in Education Conference (FIE). Institute of Electrical and Electronics Engineers, United States. 
[3] Bosch, J. (2016). Speed, Data, and Ecosystems: The Future of Software Engineering. Institute of Electrical and Electronics Engineers Software, 33(1), 82-88.

[4] Cárdenas-Castro, C., Gil, J. C. \& Rodríguez, P. (2019). Soft Skills Training: Performance Psychology Applied to Software Development. En 2019 IEEE/ACM 12 $12^{\text {th }}$ International Workshop on Cooperative and Human Aspects of Software Engineering (CHASE). Institute of Electrical and Electronics Engineers, Canada.

[5] Diel, E., Bergmann, M., Marczak, S. \& Luciano, E. (2015). What is Agile, Which Practices are Used, and Which Skills are Necessary According to Brazilian Professionals: Findings of an Initial Survey. En $20156^{\text {th }}$ Brazilian Workshop on Agile Methods (WBMA). Institute of Electrical and Electronics Engineers, Brazil.

[6] Ehlers, J. (2015). Socialness in the Recruiting of Software Engineers. En Proceedings of the $12^{\text {th }}$ ACM International Conference on Computing Frontiers. Association for Computing Machinery, Italy.

[7] Fitria \& Nugraha, I. G. B. B. (2018). Formation of Software Programmer Team Based on Skill Interdependency. En 2018 International Conference on Information Technology Systems and Innovation (ICITSI). Institute of Electrical and Electronics Engineers, Indonesia.

[8] Garousi, V., Giray, G., Tüzün, E., Catal, C. \& Felderer, M. (2019). Closing the Gap between Software Engineering Education and Industrial Needs. Institute of Electrical and Electronics Engineers Software, 37(2), 68-77.

[9] Gasca, G. P., Gómez, M. C., Manrique, B. \& Arias, D. M. (2015). Diagnostic on TeachingLearning of Software Desing by Using the Personal Software Process Framework. En $201510^{\text {th }}$ Iberian Conference on Information Systems and Technologies (CISTI). Institute of Electrical and Electronics Engineers, Portugal.

[10] Gómez, M. C., Gasca, G. P., Manrique, B. \& Arias, D. M. (2016). Method of Pedagogic Instruments Design for Software Engineering. En $201611^{\text {th }}$ Iberian Conference on Information Systems and Technologies (CISTI). Institute of Electrical and Electronics Engineers Computer Society, Spain.

[11] Humphrey, W. S. (2000). The Personal Software Process (PSP). Software Engineering Institute. Recuperado de https://resources.sei.cmu.edu/ library/asset-view.cfm?assetid=5283.
[12] López-Martín, C., Nassif, A. B. \& Abran, A. (2017). A Training Process for Improving the Quality of Software Projects Developed by a Practitioner. Journal of Systems and Software, 131, 98-111.

[13] Mann, K. S., Kumar, M. N. \& Saini, H. S. (2015). The Major Challenges for Engineering Institutions to Fulfill Industry Demands in India. En 2015 IEEE $3^{\text {rd }}$ International Conference on MOOCs, Innovation and Technology in Education (MITE). Institute of Electrical and Electronics Engineers, India.

[14] Mansoor, S., Bhutto, A., Bhatti, N., Patoli, N. \& Ahmed, M. (2017). Improvement of Students Abilities for Quality of Software Through Personal Software Process. En 2017 International Conference on Innovations in Electrical Engineering and Computational Technologies (ICIEECT). Institute of Electrical and Electronics Engineers, Pakistan.

[15] Margarov, G. \& Konovalova, V. (2019). Interdisciplinary Competencies Needed for Engineers in the Digital Economy. En 2019 Computer Science and Information Technologies (CSIT). Institute of Electrical and Electronics Engineers, Armenia.

[16] Matturro, G. (2013). Soft Skills in Software Engineering: A Study of its Demand by Software Companies in Uruguay. En 2013 $6^{\text {th }}$ International Workshop on Cooperative and Human Aspects of Software Engineering (CHASE). Institute of Electrical and Electronics Engineers, United States.

[17] Matturro, G., Raschetti, F. \& Fontán, C. (2015). Soft Skills in Software Development Teams: A Survey of the Points of View of Team Leaders and Team Members. En $20158^{\text {th }}$ International Workshop on Cooperative and Human Aspects of Software Engineering (CHASE). Institute of Electrical and Electronics Engineers, Italy.

[18] Ministerio de Tecnologías de la Información y las Comunicaciones (2015). Colombia líder en la región en la producción de software de calidad. Ministerio de Tecnologías de la Información y las Comunicaciones. Retrieved from http://www.mintic.gov.co/portal/604/w3article-8571.html.

[19] Oguz, D. \& Oguz, K. (2019). Perspectives on the Gap between the Software Industry and the Software Engineering Education. Institute of Electrical and Electronics Engineers Access, 7, 117527-117543. 
[20] Pinto, G., Ferreira, C., Souza, C., Steinmacher, I. \& Meirelles, P. (2019). Training Software Engineers Using Open-Source Software: The Students' Perspective. En 2019 IEEE/ACM $41^{\text {st }}$ International Conference on Software Engineering: Software Engineering Education and Training (ICSE-SEET). Institute of Electrical and Electronics Engineers, Canada.

[21] Rong, G., Zhang, H., Qi, S. \& Shao, D. (2016). Can Software Engineering Students Program Defect-Free? An Educational Approach. En 2016 IEEE/ACM $38^{\text {th }}$ International Conference on Software Engineering Companion (ICSE-C). Institute of Electrical and Electronics Engineers, United States.

[22] Rosca, D. (2018). Acquiring Professional Software Engineering Skills Through StudioBased Learning. En $201817^{\text {th }}$ International Conference on Information Technology Based Higher Education and Training (ITHET). Institute of Electrical and Electronics Engineers, Portugal.

[23] Thurner, V., Schlierkamp, K., Böttcher, A. \& Zehetmeier, D. (2016). Integrated Development of Technical and Base Competencies: Fostering Reflection Skills in Software Engineers to Be. En 2016 IEEE Global Engineering Education Conference (EDUCON). Institute of Electrical and Electronics Engineers Computer Society, United Arab Emirates.
[24] Tüzün , E., Erdogmus, H. \& Ozbilgin, I. G. (2018). Are Computer Science and Engineering Graduates Ready for the Software Industry? Experiences from an Industrial Student Training Program. En 2018 40 In International Conference on Software Engineering: Software Engineering Education and Training (ICSE$S E E T$ ). Institute of Electrical and Electronics Engineers, Sweden.

[25] Urbina, M. L., Abud, M. A., Peláez, G., Alor, G. \& Sánchez, A. I. (2016). Propuesta de un modelo de integración de PSP y Scrum para mejorar la calidad del proceso de desarrollo en una MiPyME. Research in Computing Science, 120, 147-157.

[26] [26] Yonamine, T., Yajima, K., Takeichi, Y., Sato, J., Kato, Y. \& Yamazaki, M. (2015). A Means for Visualization of Skills in Software Development. En $20157^{\text {th }}$ International Conference on Information Technology and Electrical Engineering (ICITEE). Institute of Electrical and Electronics Engineers, Thailand. 